\title{
Role stress and turnover intentions among information technology personnel in South Africa: The role of supervisor support
}

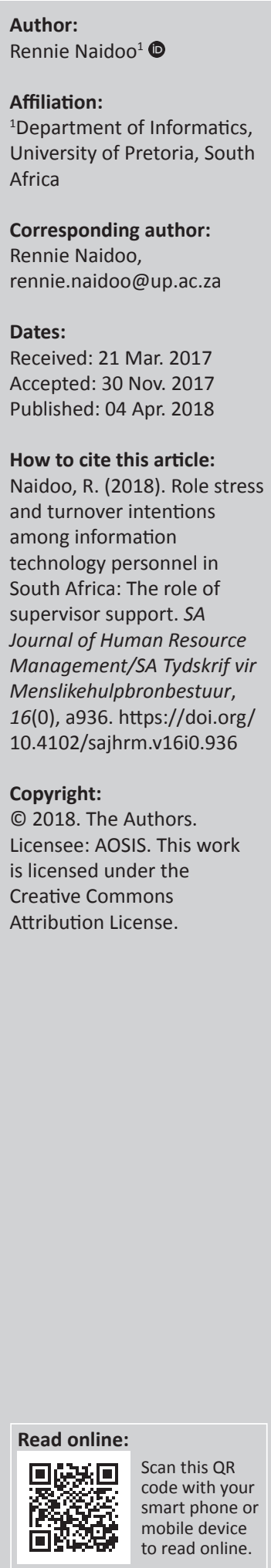

Orientation: High turnover of information technology (IT) personnel is a major problem facing many global and local organisations. An increasingly important area of turnover research of IT personnel experiencing role stress involves examining their perceptions of supervisor support.

Research purpose: This study aimed to examine the effects of role-related stress and supervisor support on job satisfaction, job performance and IT turnover intentions.

Motivations for the study: It is important to assess from both a theoretical and a practical perspective the extent to which turnover can be explained by relational factors such as supervisor support.

Research design, approach and method: An online voluntary survey yielded a sample of 163 respondents. Six constructs were measured: turnover intention, job performance, job satisfaction, supervisor support, role ambiguity and role conflict. A total of 158 usable responses were subjected to descriptive, correlation and regression analysis. Mediation and moderation effects were assessed using a multiple regression bootstrapping procedure.

Main findings: Role ambiguity has a greater impact on job satisfaction than role conflict. Job satisfaction fully mediated the relationship between role stress and turnover intention. Supervisor support mediated the relationship between role stressors and job satisfaction and role stressors and job performance. There was no evidence in favour of a moderating role of supervisor support.

Practical and managerial implications: Higher priority should be given to tackling role ambiguity. Supervisor support can increase job satisfaction, improve job performance and ultimately reduce turnover intentions, despite the presence of role stress.

Contribution or value-add: Human resource managers and IT managers could use these results to improve job performance and staff retention.

\section{Introduction}

Studies globally characterise information technology (IT) personnel as being part of the 'turnover culture' (Moore \& Burke, 2002). These norms of high turnover of IT personnel are also a persistent challenge facing many South African organisations (Igbaria, Meredith \& Smith, 1995; Smith \& Speight, 2006; Naidoo, 2016). Factors such as role ambiguity, role conflict, role overload, exhaustion, stress and burnout offer useful explanations for turnover decisions in IT (Johnson \& Stinson, 1975). A number of studies report that role-related demands, insufficient time to keep abreast with changing technologies, lack of resources and lack of support are among the primary sources of stress facing IT personnel (Ghapanchi \& Aurum, 2011). In fact, role ambiguity and role conflict are the most often cited drivers of IT turnover (Lee, 1999). The increasingly complex and demanding nature of IT work is not surprising given the rapid technological changes and concomitantly greater expectations of end users, managers and government policymakers that IT employees keep up with these changes in technology (Lim \& Teo, 1999).

In its National Integrated Information and Communication Technology (ICT) Policy White Paper (Telecommunications \& Postal Services, 2016), the South African government recognises the importance of developing and retaining IT skills. Government policymakers recognise that the IT skills supply-demand gap is a major barrier to realising their social objectives. The IT skills gap also potentially impedes private sector companies from competing effectively in local 
and global markets. Against this context of insufficient staff and resources, it is important to understand the different types of stressors experienced by IT personnel who are forced to work longer hours and serve in varied organisational roles (Ahuja, Chudoba, Kacmar, Mcknight \& George, 2007). Role-related stress is of growing concern because it has significant economic implications for the national ICT sector. Role-related stress can lead to strain on emotional and physical health of IT personnel, work exhaustion, depersonalisation, job dissatisfaction, career switching and consequently a decline in productivity in the national ICT sector (Armstrong, Brooks \& Riemenschneider, 2015). More specifically, the withdrawal behaviours of stressed IT personnel are also costly to organisations in terms of tardiness, rework, workdays lost, lateness, increased absenteeism, retirement and health costs (Jamal, 1984). Stressed IT personnel are more likely to show withdrawal behaviours such as cynicism, lack of organisational commitment, intention to leave and turnover (Moore, 2000). Moreover, those who leave add to hiring and training costs as well as investment in training and social capital losses. Meanwhile, although skilled IT workers can easily find new jobs, they also incur costs in adjusting to a new job.

While moderate levels of role-related stress can stimulate creativity and productivity (Qasim, Javed \& Shafi, 2014), excessive levels of stress in the IT work environment may hinder industry competitiveness (Cho \& Huang, 2012). However, the literature claims that strong supervisor support can relieve employee stress by improving the IT work environment (De Clercq, Dimov \& Belausteguigoitia, 2016). For example, supervisors can address employee complaints and provide them with the required resources to complete their tasks (Firth, Mellor, Moore \& Loquet, 2004). According to the buffering model of social support, employees that have good relationships with their supervisors can be productive even when they experience severe job stress (Cummins, 1990; De Clercq et al., 2016). Given the scarcity of IT talent, the critical importance of IT personnel well-being and arguably high levels of role stressors they experience, the general aim of the study is to investigate the effect of role-related stressors on turnover intentions. Furthermore, the IT literature has not addressed the role of job satisfaction as a mediator of job stressors on turnover intentions adequately. In addition, although supervisor support is important in reducing role stress, few IT studies have investigated this mediating relationship.

\section{Research purpose}

The main purpose of this study was to examine how well job role stressors influence job satisfaction in IT. It also examined the relationship between supervisor's support, job satisfaction, job performance and turnover intentions. Specifically, it addressed these four research questions:

- Which role stressor, role ambiguity or role conflict has the biggest negative influence on job satisfaction?

- To what extent is the role stressor-turnover intentions relationship mediated by job satisfaction?
- Does supervisor support moderate and/or mediate the relationship between role stressors and job satisfaction?

- Does supervisor support mediate the relationship between role stressors and job performance?

\section{Literature review Turnover and turnover intentions}

In the last 50 years, more than 1500 articles have been published on voluntary turnover (Holtom, Mitchell, Lee \& Eberly, 2008). Since 1980, close to 100 studies focused on the voluntary turnover of IT personnel alone, further reinforcing the importance of this problem in the IT sector (Ghapanchi \& Aurum, 2011; Joseph, Ng, Koh \& Ang, 2007). Voluntary turnover occurs when the decision to leave the organisation is at the employee's discretion. This is different from involuntary turnover (layoffs, forced resignations, firing) where the organisation enforces the decision. According to human capital theory, while some voluntary turnover can be functional, it generally has a negative influence on workforce performance. Firstly, voluntary turnover depletes the organisation-specific human capital accumulated by an employee. Secondly, turnover eliminates the organisation's return on its investment from a productive employee. Thirdly, high turnover can disrupt the organisation's operations, for example, managers need to redirect human resources away from maintenance and safety to product or service delivery activities. For practical reasons, most studies focus on voluntary turnover intention as opposed to voluntary turnover. Voluntary turnover intention is the estimated probability that the employee will leave the organisation (Nzukuma \& Bussin, 2011). Not surprisingly, voluntary turnover intention is also the best predictor of voluntary turnover and is a popular dependent variable for actual voluntary turnover. Although theoretical expansion of voluntary (avoidable or sometimes referred to as dysfunctional) turnover has been fruitful over the years, there continues to be a focus on stress, working relationship issues and job dissatisfaction.

\section{Job satisfaction}

Given the practical benefits for enhancing employee lives and improving the effectiveness of organisations, job satisfaction has been studied extensively in the HR literature. A popular theory of job satisfaction is the value-percept model (Judge \& Klinger, 2007). The value-percept model expresses job satisfaction in terms of what employees value and the job outcomes (Locke, 1969). This model predicts that discrepancies between employee desires and what is received are dissatisfying only if the job facet is important. While job satisfaction has several definitions, Locke (1976) defines job satisfaction as 'a pleasurable or positive emotional state resulting from the appraisal of one's job or job experiences' (Locke, 1976:1304). While this definition emphasises a cognitive (evaluative) and affective (or emotional) perspective, other conceptualisations include a behavioural component. A review by Judge and Klinger (2007) found that job satisfaction is related to a number of workplace behaviours. These include attendance, turnover decisions, decisions to retire, 
psychological withdrawal behaviours, prosocial and organisational citizenship behaviours, workplace deviance behaviour and job performance. Job satisfaction also shows a strong relationship with employee well-being (Goswami, 2014; Judge \& Klinger, 2007). However, while the literature recommends that organisations should value job satisfaction and employee well-being, it does not follow that these insights are generally applied by organisations.

\section{Role stressors and job performance}

Employees generally accept job roles because they provide important psychological benefits such as status, ego gratification and self-esteem (Chang, Jiang, Klein \& Chen, 2012; Cho \& Huang, 2012; Jiang \& Klein, 2001). Task identity, task significance, skill variety, autonomy and feedback are intrinsically motivating job characteristics (McKnight, Phillips \& Hardgrave, 2009; Payne, Fineman \& Wall, 1976) that produce positive outcomes such as job satisfaction and job performance. However, roles can also be costly when employees are not able to perform them as expected. According to role stress theory (Katz \& Kahn, 1978), employee role expectations experienced as prolonged pressure can create symptoms of ill health owing to strain and fatigue (Driscoll, Beehr, Journal \& Mar, 2016; Jamal, 1984). Employees experience role stressors in the form of increasing demands and constraints. Role stressors are composed of three distinct but related constructs: role overload, role ambiguity and role conflict. Role overload occurs when a person cannot fulfil the work within the time available. In this case, role expectations are greater than the employee's abilities and motivation to perform a task (Goswami, 2014; Holtom et al., 2008). Role ambiguity occurs when a person has inadequate information to accomplish his or her role in a satisfactory manner. In this case, the employee does not have clear authority or knowledge about how to perform the assigned job (Raman, Vijayakumar Bharathi, Sesha \& Joseph, 2013). Role conflict occurs when complying with one role makes it difficult or impossible to comply with another role. This suggests incompatible expectations and demands (Rutner et al., 2008). It is plausible that role stressors are being experienced by local IT personnel. This concept could illuminate more about IT turnover in the South African context. It is also important to investigate the relationship between role stressors and job performance.

\section{Supervisor support}

An increasingly important area of human resource management research involves examining employee perceptions of support at work (Cummins, 1990; Erturk, 2014; Karasek, Triantis \& Chaudhry, 1982). Prior research argues that employees value support from their co-supervisor more than from their coworkers or organisation (Kottke \& Sharafinski, 1988). Supervisor support is the degree to which employees perceive that supervisors care about their well-being (De Clercq et al., 2016). The perception of care and the provision of positive social interaction and resources support role demands. Turnover research has begun to consider relational variables such as supervisor support (Holtom et al., 2008; King \& Bu, 2005).

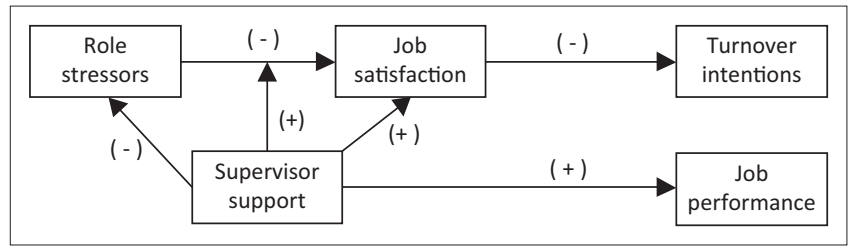

Source: Adapted from Joseph, D., Ng, K., Koh, C., \& Ang, S. (2007). Turnover of information technology professionals: A narrative review, meta-analytic structural equation modeling and model development. MIS Quarterly, 31(3), 547-577. https://doi.org/10.2307/25148807 FIGURE 1: Hypothesised model of the relationships between role stressors, supervisor support, job satisfaction, job performance and turnover intention in information technology.

Perceived supervisor support and the quality of the leadermember exchange relationship have been found to predict employee turnover (Erturk, 2014; Wayne, Shore \& Liden, 1997). In these studies, perceived supervisor support was negatively related to turnover. Furthermore, employees who perceive greater social support have greater emotional and psychological resources for coping with role stressors (Hoonakker, Carayon \& Korunka, 2013). Therefore, this study expects that the supervisor's support of IT personnel will mitigate the relationship between the role stressors that IT personnel experience and their levels of job satisfaction.

\section{The research model and hypotheses}

Figure 1 depicts a conceptual model of role stressors, supervisor support, job satisfaction and turnover intention in IT drawn from the HR, organisational and psychology literature.

\section{Hypotheses}

Role stressors are one of the ongoing challenges facing IT personnel (Ghapanchi \& Aurum, 2011). A number of IT researchers make a strong case that role stressors result in emotional exhaustion, job dissatisfaction and turnover intention (Dhar \& Dhar, 2010; Lim \& Teo, 1999; Moore, 2000). Tedium factors, such as emotional exhaustion and fatigue, are also linked to role stressors and some studies have examined similar effects of technology advancements and threats of professional obsolescence (Kim, 2005). Studies have found that role ambiguity, role conflict and role overload reduce job satisfaction and hence increase IT employee turnover intention (Calisir, Gumussoy \& Iskin, 2011). IT personnel tend to also serve multiple user communities as IT roles generally involve a high level of boundary spanning activities because of the nature of the job and the limited resources (Lim \& Teo, 1999; Moore, 2000; Mourmant, Gallivan \& Kalika, 2009; Levina \& Vaast, 2014). Studies show that IT personnel involved in boundary spanning roles are more vulnerable to role stressors. For parsimony, the two role stressors (role ambiguity and role conflict) considered here are likely to influence job satisfaction differently (Calisir et al., 2011). To test if role stressors are a determining factor in relation to job satisfaction, the first hypothesis states:

- Hypothesis 1 (H1): There is a negative association between the employee's role stress as a result of role ambiguity and role conflict on their job satisfaction, but the effects (size) will be different. 
A number of IT studies have shown that role stressors are related to lower job satisfaction (Calisir et al., 2011; Joseph et al., 2007). Substantial evidence from two recent systematic reviews found that job satisfaction is negatively related to turnover intentions (Ghapanchi \& Aurum, 2011; Joseph et al., 2007). However, few studies have tested the possibility of a meditational nature of job satisfaction (Yousef, 2014). For example, Joseph et al. (2007) found that job satisfaction significantly mediated the effects of role ambiguity and role conflict on IT turnover intention. In this study, we test the possibility of IT employees' perceptions of role stressors and turnover intentions being mediated through job satisfaction (LeRouge, Nelson \& Blanton, 2006). This leads to the second hypothesis:

- Hypothesis 2 (H2): The negative relationship between role stressors and turnover intention is mediated by job satisfaction.

Supervisor support is important in helping employees cope with stress (Jamal, 1984) and stressful situations (Karasek et al., 1982). As a result, stress does not have strong negative effects on their job satisfaction (Harris, Harris \& Harvey, 2008). On the contrary, individuals who lack supervisory support are vulnerable to the effects of role stress (Visser \& Rothmann, 2009). Empirical evidence regarding the effects of role stress is mixed (Holtom et al., 2008). Some studies have indicated that supervisor support interacts with role stressors in predicting job satisfaction, whereas other studies have not found evidence for such an interaction (Kirmeyer \& Dougherty, 1988). Other studies found that individuals who receive high levels of supervisor support cope better with stress and are more satisfied with their jobs (Erturk, 2014; Ghapanchi \& Aurum, 2011). While some studies suggest that supervisor support acts as a buffer that moderates the relationship between role stressors and job satisfaction, other studies have failed to replicate these results (Baloyi, Van Waveren \& Chan, 2014). As indicated in Figure 1, supervisor support may also play a role by linking role stress to job satisfaction. In other words, supervisor support may intervene between role stress and job satisfaction by attenuating or preventing negative role stress outcomes such as a reduction in job satisfaction. Similarly, results are equally conflicting regarding the possibility of supervisor support mediating the relationship between role stressors and job satisfaction (Baloyi et al., 2014). This study strives to clarify these results by verifying the possibility of the quality of supervisor support probably moderating and/or mediating the association between role stressors (role conflict and ambiguity) and job satisfaction. More precisely, two hypotheses will be assessed:

- Hypothesis 3 (H3): Supervisor support will moderate the relationship between role stress and job satisfaction, such that the negative relationship between role stress and job satisfaction will be weakest when supervisor support is the highest.

- Hypothesis 4 (H4): The negative relationship between role stressors and job satisfaction is mediated by supervisor support.
A few studies have suggested that supervisor support has been associated with improvements in job performance in stressful professions (AbuAlRub, 2004). The relationship between supervisor support and job performance among IT professionals requires further investigation (Igbaria \& Baroudi, 1995). Figure 1 proposes that supervisor support may intervene between role stress and job performance by attenuating or preventing negative effects on job performance (Baloyi et al., 2014). To test if supervisor support plays a determining factor in the role stressor-job performance relationship, the fifth and final hypothesis states:

- Hypothesis 5 (H5): The negative relationship between role stressors and job performance is mediated by supervisor support.

\section{Research design}

A quantitative survey was employed to collect empirical data for hypothesis testing. Many turnover studies employed a similar approach (Ghapanchi \& Aurum, 2011). Information technology personnel were targeted for this study. The target population of this study's sample was derived from the e-mailing lists of a few local IT professional bodies. Five academic researchers as well as two experienced human resource development (HRD) practitioners pretested the survey for face and content validity. Prior to the main survey, 20 postgraduate IT students volunteered to complete the pilot survey to ensure face validity of the online questionnaire. The objective of this pilot was to test if the participants understood the questions and that the full spectrum of the scale were used. Only minor changes to the questionnaire instructions and the design of the survey form were made as a result of the pre-test and pilot. The final questionnaire was divided into two main sections. Section A dealt with the demographic information of the respondents, for example, age, tenure, gender and highest educational qualification.

Section B measured the research model's six constructs. Construct measures were adapted from prior studies. Items for measuring job satisfaction were adapted from Pond and Geyer (1991). The construct's four indicators were:

- All things considered, how satisfied are you with your current job? 1 ('Very dissatisfied') to 5 ('Very satisfied').

- In general, how much do you enjoy your job? 1 ('Don't like it at all') to 5 ('Like it very much').

- Knowing what you now know, would you take up your current job again? 1 ('Definitely would not take this job') to 5 ('Would take this job without hesitation').

- How does this job compare with your ideal job? 1 ('Far from ideal') to 5 ('Close to ideal').

The remaining items were measured using a 5-point Likert scale which ranged from strongly disagree (1) to strongly agree (5). 
The turnover intention construct's three indicators adapted from Allen and Meyer (1990) were:

- I often think about quitting my job.

- As soon as I find a better job, I will leave this organisation.

- I will probably look for a new job in the near future.

The job performance construct's three indicators adapted from Welbourne and Johnson (1997) were:

- I am achieving my personal career goals at my current organisation.

- I am developing skills needed for my future career.

- I am making progress in my career.

Items measuring supervisor support were adapted from Steelman, Levy and Snell (2004). The construct's four indicators were:

- My supervisor actively listens to my suggestions.

- My supervisor enables me to perform at my best.

- My supervisor promotes an atmosphere of teamwork.

- Overall, my supervisor does a good job.

Role stressors consisted of two constructs, namely, Role conflict and role ambiguity (Firth et al., 2004). Role conflict consisted of three indicators:

- I work with two or more groups who operate quite differently.

- I receive incompatible requests from two or more people.

- I do things that are sometimes accepted by some people and not by others.

The role ambiguity construct's three indicators were:

- Clear, planned goals and objectives exist for my job.

- I know what my responsibilities are.

- I know exactly what is expected of me.

The combined email lists had approximately 1000 unique email addresses. Subjects were prompted to complete the online questionnaire via a short email. The online survey was appropriate as IT professionals were the focus of the study.

Following a single round of data collection, 163 responses were collected, giving an estimated response rate of $16.3 \%$. Five of these responses were incomplete and hence were discarded. The remaining responses were screened to identify any data entry errors as well as outliers. The final data for analysis consisted of 158 usable responses. These responses were sufficient given the number of variables and the correlation and multiple regression analysis techniques that were to be used to test the hypotheses (Hair, Anderson, Babin \& Black, 2010). The data were analysed using the Statistical Package for Social Sciences (SPSS) version 24 and the PROCESS program. The PROCESS program developed by Hayes (2012) was installed to conduct the mediation and moderation analyses. Skewness of the constructs (ranging between -0.826 for supervisor support and 0.372 for role stressors) showed that the data were not highly skewed and
Kurtosis (ranging from - 0.901 for turnover intentions to 0.611 for role stress) would not affect the results of the statistical analysis.

\section{Statistical analysis}

Principal component analysis (PCA) with a direct oblimin rotation of the 20 scale items reflecting the variables of the study (role ambiguity, role conflict, supervisor support, job satisfaction, job performance and turnover intention) was conducted to identify their linear combinations (Hair et al., 2010). The Cronbach's alpha test was used to test the internal consistency of the scale items (Hair et al., 2010). As the job stressor variables measured the same concept, a composite variable was created using the average score of the summed variables. A minimum factor loading of 0.70 would be deemed to be acceptable (Nunnally, 1967). To test Hypotheses 1, standard multiple regression was used to determine how much of variance was explained by the two job stressor constructs. Hayes (2012) PROCESS procedures were used to assess hypothesis 2, 4 and 5 (mediational) and hypothesis 3 (moderation).

\section{Ethical considerations}

Permission was granted by the University's Ethics Committee as the study complied with protocols relating to voluntary participation and anonymity of respondents.

\section{Results}

Table 1 presents the profile of the respondents. The age of the respondents varied from 20 to 65 years with a mean age of 36 years (Table 1). Of these, $67.8 \%$ were male and $32.2 \%$ were female. Although the sample consisted of a greater spread of male compared to female respondents, this response is perhaps not atypical of the South African IT work context. Only $22.8 \%$ of the sample consisted of IT professionals younger than 30 years of age. Over $70 \%$ of the respondents had 8 or more years total work experience. Although respondents had diverse educational levels (high school to doctoral study), $94.2 \%$ of the respondents reported having at least some form of tertiary education.

Prior to performing PCA, the suitability of the data for factor analysis was assessed. Inspection of the correlation matrix revealed the presence of many coefficients of 0.3 and above. The Kaiser-Meyer-Oklin value was 0.852 . This exceeds the recommended value of 0.60 . The Bartlett's Test of Sphericity reached statistical significance $(p=0.000)$, supporting the factorability of the correlation matrix. All components were retained for Eigen value greater than 1. A stable 6-factor and 20 -item solution emerged and the minimum values are shown in Table 2, which shows that results for the constructs revealed sufficiently high internal consistency for most of the scales, ranging from 0.605 to 0.924 . The response pattern for role conflict was slightly inconsistent. Although this construct was below the cut-off value of 0.70 , patterns like this sometimes occur with constructs involving few scale items. The construct was retained for further analysis. 
TABLE 1: Profile of the respondents.

\begin{tabular}{|c|c|c|}
\hline Participants & Number $(N=158)$ & Percentage \\
\hline \multicolumn{3}{|l|}{ Age } \\
\hline $20-25$ & 6 & 3.8 \\
\hline $26-30$ & 43 & 27.2 \\
\hline $31-40$ & 67 & 42.4 \\
\hline $41-50$ & 30 & 19.0 \\
\hline $51-60$ & 11 & 7.0 \\
\hline$>60$ & 1 & 0.6 \\
\hline \multicolumn{3}{|l|}{ Total work experience } \\
\hline$\leq 5$ & 31 & 19.6 \\
\hline $6-10$ & 43 & 27.2 \\
\hline $11-15$ & 36 & 22.8 \\
\hline $16-20$ & 19 & 12.0 \\
\hline$>20$ & 29 & 18.4 \\
\hline \multicolumn{3}{|l|}{ Qualification } \\
\hline High school certificate & 8 & 4.5 \\
\hline Industry certificate & 2 & 1.3 \\
\hline Some university & 22 & 14.0 \\
\hline $\begin{array}{l}\text { College (e.g. certificate/ } \\
\text { diploma) }\end{array}$ & 19 & 12.1 \\
\hline Diploma & 36 & 22.9 \\
\hline Degree (3 year) & 35 & 22.3 \\
\hline Honours (4 years) & 27 & 17.2 \\
\hline Master's & 3 & 1.9 \\
\hline Doctorate & 6 & 3.8 \\
\hline \multicolumn{3}{|l|}{ Gender } \\
\hline Male & 107 & 67.8 \\
\hline Female & 51 & 32.2 \\
\hline
\end{tabular}

TABLE 2: Mean, standard deviation and construct reliabilities.

\begin{tabular}{lccccc}
\hline Constructs & Items & Mean & $\begin{array}{c}\text { Standard } \\
\text { deviation }\end{array}$ & $\begin{array}{c}\text { Cronbach's } \\
\text { alpha }\end{array}$ & $\begin{array}{c}\text { Minimum } \\
\text { factor loading }\end{array}$ \\
\hline Role conflict & 3 & 3.65 & 0.82 & $0.605 \dagger$ & 0.691 \\
$\begin{array}{l}\text { Role } \\
\text { ambiguity }\end{array}$ & 3 & 2.19 & 0.82 & 0.827 & 0.748 \\
$\begin{array}{l}\text { Supervisor } \\
\text { support }\end{array}$ & 4 & 3.69 & 0.99 & 0.924 & 0.769 \\
$\begin{array}{l}\text { Job } \\
\text { satisfaction }\end{array}$ & 4 & 3.42 & 0.93 & 0.901 & 0.750 \\
$\begin{array}{l}\text { Job } \\
\text { performance }\end{array}$ & 3 & 3.34 & 0.99 & 0.885 & 0.727 \\
$\begin{array}{l}\text { Turnover } \\
\text { intention }\end{array}$ & 3 & 3.16 & 1.19 & 0.881 & 0.766 \\
\hline
\end{tabular}

$N=158$.

$\dagger$, Construct below the normal cut-off of 0.70 .

TABLE 3: Correlation matrix for job stressors, supervisor support, job satisfaction and job performance on employee turnover intention.

\begin{tabular}{lccccc}
\hline Variable & $\mathbf{( 1 )}$ & $\mathbf{( 2 )}$ & $\mathbf{( 3 )}$ & $\mathbf{( 4 )}$ & (5) \\
\hline Turnover intention (DV) & 1.000 & - & - & - & - \\
Role stressors & 0.257 & 1.000 & - & - & - \\
Supervisor support & -0.402 & -0.436 & 1.000 & - & - \\
Job satisfaction & -0.520 & -0.270 & 0.449 & 1.000 & - \\
Job performance & -0.368 & -0.221 & 0.475 & 0.542 & 1.000 \\
\hline
\end{tabular}

$N=158$.

Turnover intention is the dependent variable (DV).

All correlations are statistically significant at $p<0.01$

Results of the analysis, along with descriptive statistics (item means and standard deviations), are presented in Table 2. While the mean score for turnover intention (mean $=3.16$, $\mathrm{SD}=1.19$ ) appeared neutral, the SD score suggest a wide difference of opinion among respondents. Job performance scores (mean $=3.34, \mathrm{SD}=0.99)$ appeared somewhat neutral. Role ambiguity scores (mean $=2.19, \mathrm{SD}=0.82$ ) were
TABLE 4: Regression analysis of role stress on job satisfaction.

\begin{tabular}{lccc}
\hline Independent variable & $\boldsymbol{b}$ & $\boldsymbol{t}$ & $\boldsymbol{p}$ \\
\hline Role stressors & $-0.270^{*}$ & -3.496 & 0.001 \\
$R^{2}$ & 0.073 & - & - \\
\hline
\end{tabular}

$b$, standardised beta; $t, t$ test statistic; $p$, probability value.

$*, p<0.05$

$R^{2}, R$-squared (coefficient of determination)

generally low. Role conflict scores $($ mean $=3.65, \mathrm{SD}=0.82$ ) suggest that this stressor was prevalent in their jobs. Scores for job satisfaction (mean $=3.42, \mathrm{SD}=0.93$ ) suggest that many respondents were only slightly satisfied with their jobs. Supervisor support had the highest performance score $($ mean $=3.69, \mathrm{SD}=0.99)$.

Table 3 shows that the scales were tested for independence using Pearson's product-moment correlation. All correlations were significant at $p<0.01$ levels. The composite role stressor construct had a small positive relationship with turnover intention $(r=0.257, n=158, p<0.01)$. Job satisfaction has a strong negative relationship with turnover intention $(r=-0.520, n=158, p<0.01)$. Job performance has a moderately negative relationship with turnover intention $(r=-0.368$, $n=158, p<0.01$ ) and a moderately positive relationship with supervisor support $(r=-0.475, n=158, p<0.01)$. Supervisor support has a moderately negative relationship with turnover intention $(r=-0.402, n=158, p<0.01)$. The correlation between job satisfaction and supervisor support $(r=0.448, n=158$, $p<0.01)$ was also moderate. Preliminary analyses were performed to ensure no violation of the assumptions of normality, linearity and homoscedasticity existed. Intercorrelations among scales did not exceed 0.70 , therefore the independence of the scales was considered adequate for this study.

Hypothesis 1 predicted a negative relationship between role stressors and job satisfaction. The standard regression analysis presented in Table 4 supports hypothesis 1 . Further analysis compared the independent contribution of role ambiguity and role conflict to job satisfaction. The beta-value for role ambiguity (beta $=-0.273, p<0.001$ ) was higher than role conflict (beta $=-0.123, p<0.174$, NS, nonsignificant) and statistically significant, suggesting that only role ambiguity made a unique contribution to predicting job satisfaction.

Hypothesis 2 proposed that job satisfaction mediates the relationship between role stressors and turnover intention. Hayes' (2012) PROCESS macro for statistical mediation analysis was applied once it was verified that the data had met the assumptions of linearity, normally distributed errors and uncorrelated errors. Table 5 shows the means, standard deviations and intercorrelations. Figure 2 shows the values of $b$ and $p$ for the effects. As Figure 3 illustrates, the standardised regression coefficient between role stress and job satisfaction was statistically significant, as was the standardised regression coefficient between job satisfaction and turnover intentions. These results support the mediational hypothesis. Role stressor was no longer a significant predictor of turnover intentions after controlling for the mediator, job satisfaction, $b=0.262, \mathrm{SE}=0.146$, ns, consistent with full mediation. 
TABLE 5: Means, standard deviations and intercorrelations for job satisfaction, role stressors and turnover intentions.

\begin{tabular}{lccccc}
\hline Variable & Mean & $\begin{array}{c}\text { Standard } \\
\text { Deviation }\end{array}$ & $\mathbf{1}$ & $\mathbf{2}$ & $\mathbf{3}$ \\
\hline Job satisfaction & 3.42 & 0.93 & - & -0.270 & -0.520 \\
Role stressors & 2.92 & 0.57 & - & - & 0.257 \\
Turnover intentions & 3.16 & 1.19 & - & - & - \\
\hline
\end{tabular}

$N=158$.

Turnover intention is the dependent variable (DV).

All correlations are statistically significant at $p<0.01$

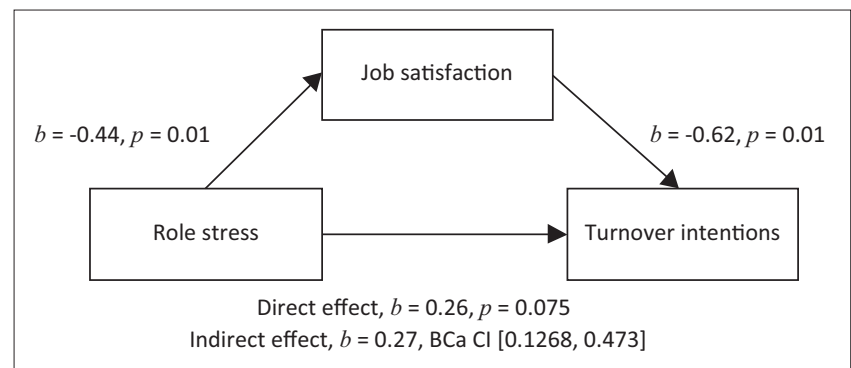

$b$, standardised beta; $p$, probability value; $\mathrm{BCa} \mathrm{Cl}$, bootstrapped confidence interval.

FIGURE 2: Diagram of the job satisfaction mediation model with regression coefficients, indirect effects and bootstrapped confidence intervals.

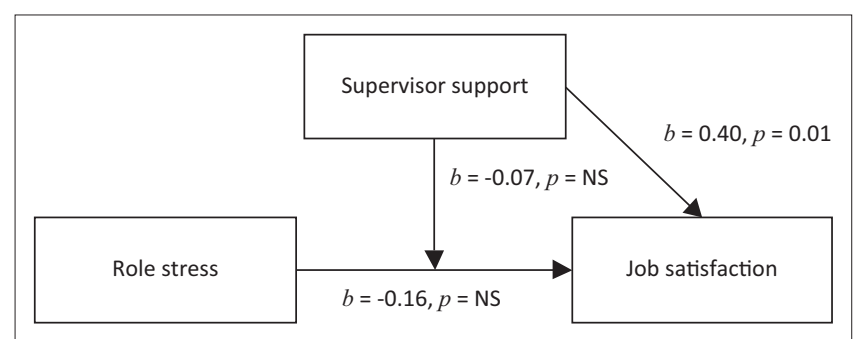

$b$, standardised beta; $p$, probability value; $\mathrm{BCa} \mathrm{Cl}$, bootstrapped confidence interval.

FIGURE 3: Diagram of the job satisfaction moderation model with regression coefficients and interaction effect.

TABLE 6: Multiple regression analysis' summary for role stressors and job satisfaction moderated by supervisor support.

\begin{tabular}{lcccc}
\hline Variable & $\boldsymbol{b}$ & $\begin{array}{c}\text { Standard error of } \\
\text { the B coefficient }\end{array}$ & $\boldsymbol{t}$ & $\boldsymbol{p}$ \\
\hline $\begin{array}{l}\text { Supervisor } \\
\text { support (centred) }\end{array}$ & 0.3965 & 0.0775 & 5.1149 & $<0.001$ \\
$\begin{array}{l}\text { Role stress (centred) } \\
\begin{array}{l}\text { Role stress } \times \\
\text { supervisor support }\end{array}\end{array}$ & -0.1550 & 0.1480 & -1.0471 & NS \\
\begin{tabular}{l} 
Constant \\
\hline
\end{tabular} & -0.0691 & 0.0890 & -0.7767 & NS \\
\hline
\end{tabular}

$b$, standardised beta; $t, t$ test statistic; $p$, probability value.

NS, nonsignificant at the 0.05 probability level.

$N=158 ; R^{2}=0.21 ; F(3,154)=16.54, p<0.01$.

TABLE 7: Means, standard deviations and intercorrelations for supervisor support, role stressors and for job satisfaction.

\begin{tabular}{lccccc}
\hline Variable & Mean & $\begin{array}{c}\text { Standard } \\
\text { deviation }\end{array}$ & $\mathbf{1}$ & $\mathbf{2}$ & $\mathbf{3}$ \\
\hline Supervisor support & 3.69 & 0.99 & - & -0.436 & 0.449 \\
Role stressors & 2.92 & 0.57 & - & - & -0.270 \\
Job satisfaction & 3.42 & 0.93 & - & - & - \\
\hline
\end{tabular}

$N=158$.

Job Satisfaction is the dependent variable (DV)

All correlations are statistically significant at $p<0.01$

The indirect effect of X on $Y$, the model with the relationship between role stressor and turnover intentions being mediated by job satisfaction, were computed for 1000 bootstrapped samples at the 95\% confidence interval (Hayes, 2013).
The indirect effect was statistically significant. Thus, this analysis confirms that job satisfaction fully mediates the relationship between role stressors and turnover intentions, $b=0.27$, bias-corrected and accelerated (BCa) bootstrap confidence interval (CI) $(0.1268,0.473)$.

Hypothesis 3 proposed that supervisor support would moderate the relationship between role stressors and job satisfaction. Once again, the data met the assumptions of linearity, normally distributed errors and uncorrelated errors. Hayes' (2012) PROCESS macro for statistical moderation analysis was applied to determine if supervisor moderates the relationship between role stressors and job satisfaction. A statistically significant interaction was found $[F(3,154)=16.54, p<0.001, R$ squared $=0.21]$ for the model of supervisor support, role stress and the interaction of role stress and supervisor support. This model predicts $21 \%$ of the variance in job satisfaction. Table 6 , however, shows that the interaction effect of role stress $\times$ supervisor support was not significant, suggesting that supervisor support was not moderating the relationship between role stressors and job satisfaction.

There was no statistically significant negative relationship between role stress and job satisfaction $[b=-0.87,95 \% \mathrm{CI}$ $(-0.349,0.176), t=-0.6516, p=\mathrm{NS}]$. When supervisor support was at the mean, there was no statistically significant negative relationship between role stress and job satisfaction $[b=-0.16$, 95\% CI (-0.447, -0.1374), $t=-1.0471, p=$ NS]. Finally, when supervisor support was high, there was no statistically significant negative relationship between role stress and job satisfaction $[b=-0.22,95 \%$ CI $(-0.627,-0.1801), t=-1.0937, p=$ NS]. Both sets of predictor data were centred using the PROCESS command to conduct a slope analysis (Hayes, 2012). The pattern derived from the results diagrammed in Figures 4 and 5 confirms the existence of a main effect for supervisor support but not for an interaction effect of role stress (RSt) $\times$ supervisor support (SUPS) on job satisfaction (JS).

Hypothesis 4 proposed that supervisor support would play a mediating role between role stressors and job satisfaction. Table 7 shows the means, standard deviations and intercorrelations. Figures 4 and 5 confirm that supervisor support fully mediates the relationship between role stressors and job satisfaction $[b=-0.29$, BCa CI $(-0.4634,-1.694)]$.

Hypothesis 5 proposed that supervisor support would also play a mediating role between the role stressors and job performance. Table 8 shows the means, standard deviations and intercorrelations. Figure 6 shows the values of $b$ and $p$ for the effects. The analysis confirms that supervisor support fully mediates the relationship between role stressors and job performance $[b=-0.35$, BCa CI $(-0.533,-0.208)]$.

\section{Discussion}

This research examined how role stressors influenced job satisfaction among IT personnel, the extent to which the role stressor-turnover intentions relationship is mediated by job 


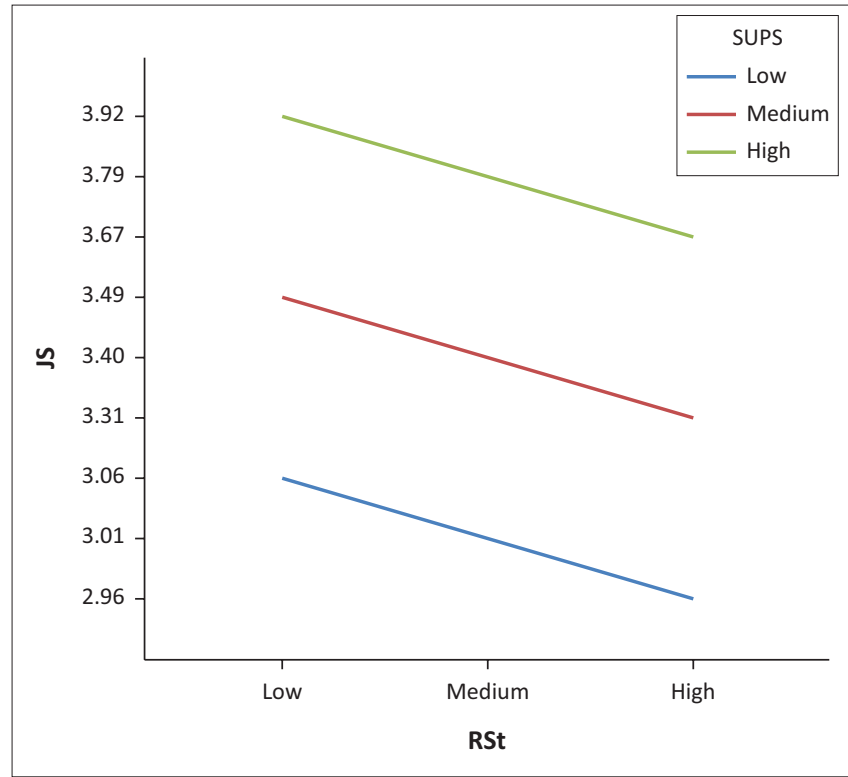

RSt, role stress; SUPS, supervisor support; JS, job satisfaction.

FIGURE 4: Graphing the interaction effects of role stressors and supervisor support in the prediction of job satisfaction.

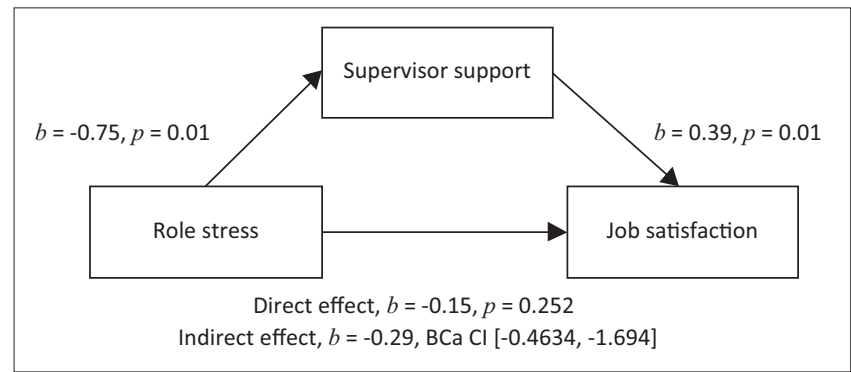

$b$, standardised beta; $p$, probability value; $\mathrm{BCa} \mathrm{Cl}$, bootstrapped confidence interval.

FIGURE 5: Diagram of the supervisor support mediation model with regression coefficients, indirect effects and bootstrapped confidence intervals.

TABLE 8: Means, standard deviations and intercorrelations for supervisor support, role stressors and for job performance.

\begin{tabular}{lccccc}
\hline Variable & Mean & $\begin{array}{c}\text { Standard } \\
\text { deviation }\end{array}$ & $\mathbf{1}$ & $\mathbf{2}$ & $\mathbf{3}$ \\
\hline $\begin{array}{l}\text { Supervisor } \\
\text { support }\end{array}$ & 3.69 & 0.99 & - & -0.270 & 0.475 \\
$\begin{array}{l}\text { Role stressors } \\
\text { Job }\end{array}$ & 2.92 & 0.57 & - & - & -0.221 \\
performance & 3.34 & 0.99 & - & - & - \\
\hline
\end{tabular}

$N=158$.

Turnover intention is the dependent variable (DV).

All correlations are statistically significant at $p<0.01$

satisfaction, the extent to which the role stressor job satisfaction relationship is moderated and/or mediated by supervisor support and the extent to which the role stressorjob performance relationship is also mediated by supervisor support. The results from the empirical study of 158 IT personnel supports Hypotheses 1, 2, 4 and 5. The results provided no evidence in favour of Hypotheses 3 which proposed a moderating role of supervisor support.

As predicted, there was a negative relationship between role stressors and job satisfaction. Furthermore, in this study, the role stressor, role ambiguity, was the sole predictor of turnover intention (and not role conflict). The negative

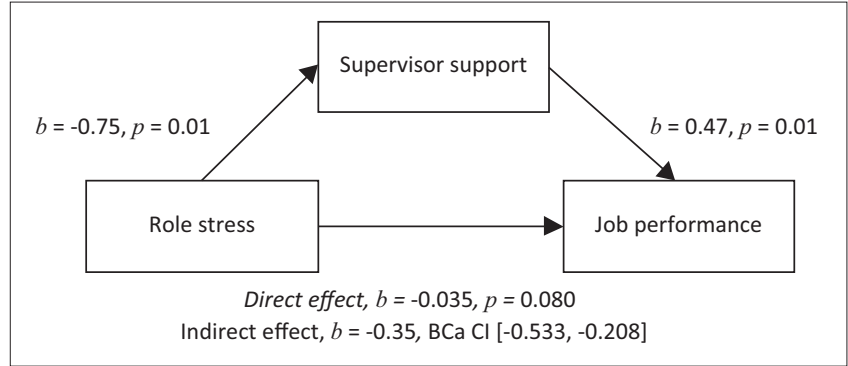

$b$, standardised beta; $p$, probability value; $\mathrm{BCa} \mathrm{Cl}$, bootstrapped confidence interval. FIGURE 6: Diagram of the supervisor support mediation model with regression coefficients, indirect effects and bootstrapped confidence intervals.

influence of role ambiguity compared with other role stressors has been noted by other researchers (Zhao \& Rashid, 2010). Still, it is interesting that IT personnel in South Africa have a higher tolerance for role conflict than for role ambiguity. Role ambiguity issues around aspects, such as unclear or inadequate information or lack of authority to accomplish tasks, remain a major concern.

Furthermore, this study emphasises the importance of adopting strategies to deliver more supervisor support for IT personnel in the workplace (Krishnan \& Singh, 2010; Lacity, Iyer \& Rudramuniyaiah, 2009; Thatcher, Liu, Stepina, Goodman \& Treadway, 2006). There is clear evidence that role stressors are a risk that leads to turnover intentions among IT personnel. However, the findings in this research suggest that supervisor support and job satisfaction function as mediators in this relationship. The results provided no evidence in favour of the so-called buffering effect or moderating role of supervisor support.

The mediating role of supervisor support on influencing role conflict and role ambiguity on job satisfaction suggest that employees who perceive higher levels of role conflict and role ambiguity would be less satisfied with their job and consequently have higher intentions to leave the organisation. Supervisor support considerably increased job satisfaction despite the presence of role stress. It is likely that the IT staff's relationship with supervisors enabled them to handle the presence of role stress by either decreasing the threats associated with role-related issues or by increasing the motivational resources available to cope with role-related issues.

Information Technology personnel who report higher levels of supervisor support and greater job satisfaction have better relational and psychological resources for coping with role stressors. These forms of coping, in turn, lead to lower intentions to leave among employees. So supervisor support and job satisfaction are two mechanisms that the organisation can use to mitigate the risk of role stressors. The role of supervisor support is not limited to reducing the effects of role stressors on turnover intentions. Supervisors also need to play an active role in the career development opportunities for employees. There is clear evidence from this study that supervisor support also encourages better job performance even in the presence of job stressors. Finally, despite 
innovative job designs based on concepts such as selfmanagement, agility and autonomous work teams, this study provides evidence that supervisor support remains vital in reducing the impact of role stress, increasing job satisfaction and improving the job performance of IT personnel.

\section{Practical implications}

The current social and business climate places extra demands on IT employees and involves various role stressors, especially role ambiguity. One practical implication of this research is that role ambiguity has a much greater impact on turnover intention than role conflict, so organisations should give the highest priority to tackling role ambiguity in managing role stress. The second practical implication of the findings is the importance of supervisor support as an intervention in the presence of role stress. The third practical implication of these findings is the importance of keeping job satisfaction as high as possible in the presence of role stressors. The findings suggest that much of the impact of role stressors on turnover intentions goes through job satisfaction and if management can find ways to increase job satisfaction, they may be able to retain their employees even though role stress is present. Supervisor support and being sensitive to job satisfaction needs can go a long way in compensating for the negative effects of role stressors.

\section{Limitations and recommendations}

The present research has several limitations that should be noted. Firstly, the study drew from a sample frame of IT professionals. Therefore, these findings must be confirmed for other types of IT workers. Secondly, the study also suffered from biases inherent in most voluntary survey-based research. In the case of this survey, the responses were skewed towards respondents who were receiving high degrees of supervisor support. Furthermore, this survey was limited to views of relatively older and more experienced IT professionals. Thirdly, supervisor support was the only relational resource investigated in reducing role stress. There are potentially more valuable relational resources. For example, future studies can examine the influence of organisational support, co-worker support, supervisor support and even family support. Prior research has also shown that the relationship between role stressors and intention to quit may vary widely, depending on the functional role and level of employees. Future studies could focus on the broader organisational hierarchy in IT and IT job types, and investigate how these differences may influence role stress and turnover. Finally, this study assumes that role stressors are generally constraining in nature. However, sometimes stressful demands can lead to personal development (Qasim et al., 2014). Future research could investigate the potential gains of role stress for individuals under certain conditions.

\section{Conclusion}

Despite the recent innovative job designs in IT, based on concepts such as self-management, agility and autonomous work teams, this study provides evidence that traditional relational support structures such as supervisor support are still vital in improving overall job satisfaction and job performance of IT personnel, in the presence of role stress. Supervisors are crucial in helping IT personnel to remain satisfied and to perform well in spite of role stress. This relational support ultimately contributes to the retention of scarce IT talent. To improve staff retention, human resource managers, IT managers as well as IT supervisors could use these results to manage role stressors by also increasing job satisfaction to prevent unwanted turnover. Studies of relational support in IT can provide IT leaders in this era of increasing role changes and work-related stress with new insights on how to improve employee performance and IT talent retention.

\section{Acknowledgements Competing interests}

The author declares that he has no financial or personal relationships that may have inappropriately influenced him in writing this article.

\section{References}

AbuAIRub, R.F. (2004). Job stress, job performance, and social support among hospital nurses. Journal of Nursing Scholarship, First Quarter, 36(1), 73-78. https://doi. org/10.1111/j.1547-5069.2004.04016.x

Ahuja, M.K., Chudoba, K.M., Kacmar, C.J., Mcknight, D.H., \& George, J.F. (2007). IT road warriors: Balancing work-family conflict, job autonomy, and work overload to mitigate turnover intentions. MIS Quarterly, 31(1), 1-17. https://doi. org $/ 10.2307 / 25148778$

Allen, N.J., \& Meyer, J.P. (1990). The measurement and antecedents of affective, continuance and normative commitment to the organization. Journal of continuance and normative commitment to the organization. Journal of
Occupational Psychology, 63(1), 1-18. https://doi.org/10.1111/j.2044-8325.1990. Occupational

Armstrong, D.J., Brooks, N.G., \& Riemenschneider, C.K. (2015). Exhaustion from information system career experience: Implications for turn-away intention. MIS Quarterly, 39(3), 713-727. https://doi.org/10.25300/MISQ/2015/39.3.10

Baloyi, S., Van Waveren, C., \& Chan, K.-Y. (2014). The role of supervisor support in predicting employee job satisfaction from their perception of the performance management system. South African Journal of Industrial Engineering, 25(1), 85-95. https://doi.org/10.7166/25-1-739

Calisir, F., Gumussoy, C.A., \& Iskin, I. (2011). Factors affecting intention to quit among IT professionals. Personnel Review, 40(4), 514-533. https://doi.org/ 10.1108/00483481111133363

Chang, C.L.H., Jiang, J.J., Klein, G., \& Chen, H.G. (2012). Career anchors and disturbances in job turnover decisions - A case study of IT professionals in Taiwan. Information and Management, 49(6), 309-319. https://doi.org/10.1016/j. im.2012.08.002

Cho, V., \& Huang, X. (2012). Professional commitment, organizational commitment, and the intention to leave for professional advancement: An empirical study on IT professionals. Information Technology \& People, 25(1), 31-54. https://doi.org/ 10.1108/09593841211204335

Cummins, R.C. (1990). Job stress and the buffering effect of supervisory support. Group \& Organization Management, 15(1), 92-104. https://doi.org/10.1177/ 105960119001500107

De Clercq, D., Dimov, D., \& Belausteguigoitia, I. (2016). Perceptions of adverse work conditions and innovative behavior: The buffering roles of relational resources. Entrepreneurship: Theory and Practice, 4O(3), 515-542. https://doi.org/10.1111/ etap.12121

Dhar, R.L., \& Dhar, M. (2010). Job stress, coping process and intentions to leave: A study of information technology professionals working in India. Social Science Journal, 47(3), 560-577. https://doi.org/10.1016/j.soscij.2010.01.006

Driscoll, M.P.O., Beehr, T.A., Journal, S., \& Mar, N. (2016). Supervisor behaviors, role stressors and uncertainty as predictors of personal outcomes for subordinates. JST, 15(2), 141-155.

Erturk, A. (2014). Influences of HR practices, social exchange, and trust on turnover intentions of public IT professionals. Public Personnel Management, 43(1), 140-175. https://doi.org/10.1177/0091026013517875

Firth, L., Mellor, D.J., Moore, K.A., \& Loquet, C. (2004). How can managers reduce employee intention to quit? Journal of Managerial Psychology, 19(2), 170-187. https://doi.org/10.1108/02683940410526127

Ghapanchi, A.H., \& Aurum, A. (2011). Antecedents to IT personnel's intentions to leave: A systematic literature review. Journal of Systems and Software, 84(2), 238-249. https://doi.org/10.1016/j.jss.2010.09.022 
Goswami, S. (2014). Work-life conflict among IT professionals. The IUP Journal of Organizational Behavior, XIII(4), 38-59.

Hair, J.F., Anderson, R.E., Babin, B.J., \& Black, W.C. (2010). Multivariate data analysis: A global perspective. Cape Town: Pearson.

Harris, R.B., Harris, K.J., \& Harvey, P. (2008). An examination of the impact of supervisor on the relationship between job strains and turnover intention for computer workers. Journal of Applied Social Psychology, 38(8), 2108-2131. https://doi.org/10.1111/j.1559-1816.2008.00383.x

Hayes, A.F. (2012). PROCESS: A versatile computational tool for observed variable mediation, moderation, and conditional process modeling. Retrieved October 14 2017, from http://www.processmacro.org/index.html

Hayes, A.F. (2013). Introduction to mediation, moderation, and conditional process analysis: A regression-based approach. New York: Guilford Press.

Holtom, B.C., Mitchell, T.R., Lee, T.W., \& Eberly, M.B. (2008). Turnover and retention research: A glance at the past, a closer review of the present, and a venture into the future. The Academy of Management Annals, 2(1), 231-274. https://doi org/10.1080/19416520802211552

Hoonakker, P., Carayon, P., \& Korunka, C. (2013). Using the job-demands-resources model to predict turnover in the information technology workforce - General modfects and gender differences. Horizons of Psychology, 22, 51-65.

Igbaria, M., \& Baroudi, J. (1995). The impact of job performance evaluations on caree advancement prospect : An examination of gender differences in the IS workplace. MIS Quarterly, 19(1), 107-123. https://doi.org/10.2307/249713

Igbaria, M., Meredith, G., \& Smith, D.C. (1995). Career orientations of information systems employees in South Africa. Journal of Strategic Information Systems, 4(4), 319-340. https://doi.org/10.1016/0963-8687(95)80002-8

Jamal, M. (1984). Job stress and job performance controversy: An empirical assessment. Organizational Behavior and Human Performance, 33(1), 1-21. https://doi.org/10.1016/0030-5073(84)90009-6

Jiang, J., \& Klein, G. (2001). Supervisor and career anchor on the career satisfaction of the entry-level information systems professional. Journal of Managemen Information System, 16(3), 219-240. https://doi.org/10.1080/07421222.1999.11 518262

Johnson, T.W., \& Stinson, J.E. (1975). Role ambiguity, role conflict, and satisfaction Moderating effects of individual differences. The Journal of Applied Pychology 60(3), 329-333. https://doi.org/10.1037/h0076752

Joseph, D., Ng, K., Koh, C., \& Ang, S. (2007). Turnover of information technology professionals: A narrative review, meta-analytic structural equation modeling and model development. MIS Quarterly, 31(3), 547-577. https://doi.org/ 10.2307/25148807

Judge, T.A., \& Kinger, R. (2007). Job satisfaction: Subjective well-being at work. In M. Eid \& R. Larsen (Eds.), The science of subjective well-being (pp. 393-413) New York: Guilford Publications.

Karasek, R.A., Triantis, K.P., \& Chaudhry, S.S. (1982). Coworker and supervisor support as moderators of associations between task characteristics and mental strain. Journal of Organizational Behavior, 3(2), 181-200. https://doi.org/10.1002/ journal of Organiz

Katz, D., \& Kahn, R. (1978). The social psychology of organizations. New York: Wiley.

Kim, S. (2005). Factors affecting state government information technology employee turnover intentions. The American Review of Public Administration, 35(2), 137156. https://doi.org/10.1177/0275074004273150

King, R.C., \& Bu, N. (2005). Perceptions of the mutual obligations between employee and employers: A comparative study of new generation IT professionals in China and the United States. The International Journal of Human Resource Management, 16(1), 46-64. https://doi.org/10.1080/0958519042000295948

Kirmeyer, S.L., \& Dougherty, T.W. (1988). Work load, tension, and coping: Moderating effects of supervisor support. Personnel Psychology, 41(1), 125-139. https://doi. org/10.1111/j.1744-6570.1988.tb00635.x

Kottke, J., \& Sharafinski, C. (1988). Measuring perceived supervisory and organizational support. Educational and Psychological Measurement, 48(4), 1075-1079. https:// doi.org/10.1177/0013164488484024

Krishnan, S.K., \& Singh, M. (2010). Outcomes of intention to quit of Indian it professionals. Human Resource Management, 49(3), 421-437. https://doi.org/ 10.1002/hrm.20357

Lacity, M.C., Iyer, V.V., \& Rudramuniyaiah, P.S. (2009). Turnover intentions of Indian IS professionals. Information Systems Outsourcing (Third Edition): Enduring Themes, Global Challenges, and Process Opportunities, 2004, 393-421. https://doi.org/ Global Challenges, and Process

Lee, P.C.B. (1999). Turnover of information technology professionals: A contextual model. Accounting, Management and Information Technologies, 10(2), 101-124. hodel. Accounting, Management and Information

LeRouge, C., Nelson, A., \& Blanton, J.E. (2006). The impact of role stress fit and selfesteem on the job attitudes of IT professionals. Information and Management, 43(8), 928-938. https://doi.org/10.1016/j.im.2006.08.011

Levina, N., \& Vaast, E. (2014). Innovating or doing as told? Status differences and overlapping boundaries in offshore collaboration. MIS Quarterly, 32(2), 307-332. https://doi.org/10.2307/25148842
Lim, V.K.G., \& Teo, T.S.H. (1999). Occupational stress and IT personnel in Singapore: Factorial dimensions and differential effects. International Journal of Information Management, 19(4), 277-291. https://doi.org/10.1016/S0268 4012(99)00027-4

Locke, E.A. (1969). What is job satisfaction? Organizational Behavior and Human Performance, 4, 309-336. https://doi.org/10.1016/0030-5073(69)90013-0

Locke, E.A. (1976). The nature and causes of job satisfaction. In M.D. Dunnette (Ed.), Handbook of industrial and organizational psychology (pp. 1297-1349), New York: Holt, Reinhart \& Winston.

McKnight, D.H., Phillips, B., \& Hardgrave, B.C. (2009). Which reduces IT turnover intention the most: Workplace characteristics or job characteristics? Information and Management, 46(3), 167-174. https://doi.org/10.1016/j.im.2009.01.002

Moore, J.E. (2000). One road to turnover: An examination of work exhaustion in technology professionals. MIS Quarterly, 24(1), 141-168. https://doi.org/10.2307/ 3250982

Moore, J.E., \& Burke, L.A. (2002). How to turn around 'turnover culture' in IT. Communications of the ACM, 45(2), 73-78. https://doi.org/10.1145/ 503124.503126

Mourmant, G., Gallivan (Mike), M.J., \& Kalika, M. (2009). Another road to IT turnover: The entrepreneurial path. European Journal of Information Systems, turnover: The entrepreneurial path. European Journ

Naidoo, R. (2016), A communicative-tension model of change-induced collective voluntary turnover in IT, The Journal of Strategic Information Systems, 25(4), 277-298.

Nunnally, J.C. (1967). Psychometric theory. New York: McGraw-Hill Series in Psychology.

Nzukuma, K.C.C., \& Bussin, M. (2011). Job-hopping amongst African Black senio management in South Africa. SA Journal of Human Resource Management, 9(1) 1-13. https://doi.org/10.4102/sajhrm.v9i1.360

Payne, R.L., Fineman, S., \& Wall, T.D. (1976). Organizational climate and job satisfaction: A conceptual synthesis. Organizational Behavior and Human Performance, 16, 45-62. https://doi.org/10.1016/0030-5073(76)90006-4

Pond, S.B., \& Geyer, P.D. (1991). Differences in the relation between job satisfaction and perceived work alternatives among older and younger blue-collar workers. Journal of Vocational Behavior, 39(2), 251-262. https://doi.org/10.1016/0001 Journal of Vocationa

Qasim, T., Javed, U., \& Shafi, M.S. (2014). Impact of stressors on turnover intention : Examining the role of employee well-being, International Journal of Social, Management, 8(1), 176-184.

Raman, R., Vijayakumar Bharathi, S., Sesha, V., \& Joseph, S. (2013). Use of structural equation modeling to empirically study the turnover intentions of information technology professionals in Pune city. Indian Journal of Science and Technology, 6(12), 5612-5624

Rutner, P.S., Rutner, P.S., Hardgrave, B.C., Hardgrave, B.C., McKnight, D.H., \& McKnight, D.H. (2008). Emotional dissonance and the information technology professional. MIS Quarterly, 32(3), 635-652. https://doi.org/10.2307/25148859

Smith, D.C., \& Speight, H.L. (2006). Antecedents of turnover intention and actual turnover among information systems personnel in South Africa. In Proceedings of the 2006 ACM SIGMIS CPR Conference on Computer Personnel Research Forty Four Years of Computer Personnel Research: Achievements, Challenges \& the Future - SIGMIS CPR '06 (p. 123-129), Claremont, California, April 13-15, ACM Press, Germany. https://doi.org/10.1145/1125170.1125205

Steelman, L.A., Levy, P.E., \& Snell, A.F. (2004). The feedback environment scale: Construct definition measurement, and validation. Educational and Psychological Measurement, 64(1), 165-184. https://doi.org/10.1177/0013164403258440

Telecommunications \& Postal Services. (2016). National integrated ICT policy White Paper. Pretoria. Retrieved January 14, 2017, from https://www.dtps.gov.za/ images/phocagallery/Popular_Topic_Pictures/National_Integrated_ICT_Policy White.pdf

Thatcher, J.B., Liu, Y., Stepina, L.P., Goodman, J.M., \& Treadway, D.C. (2006). IT worker turnover: An empirical examination of intrinsic motivation. ACM SIGMIS Database, 37(2-3), 133-146. https://doi.org/10.1145/1161345.1161361

Visser, W., \& Rothmann, S. (2009). The development of a hassle-based diagnostic scale for predicting burnout in call centres. SA Journal of Human Resource Management 7(1), 1-8. https://doi.org/10.4102/sajhrm.v7i1.181

Wayne, S.J., Shore, L.M., \& Liden, R.C. (1997). Perceived organizational support and leader- member exchange: A social exchange perspective. Academy of Management Journal, 40(1), 82-111. https://doi.org/10.2307/257021

Welbourne, T.M., \& Johnson, D.E. (1997). The role-based performance scale: Validity analysis of a theory-based measure (No. \#97-05). Ithaca, NY. Retrieved July 25, 2009, from http://digitalcommons.ilr.cornell.edu/cahrswp/147

Yousef, D.A. (2002). Job satisfaction as a mediator of the relationship between job stressors and affective, continuance, and normative commitment: A path analytical approach. International Journal of Stress Management, 9(2), 99-112. https://doi.org/10.1023/A:1014954703735

Zhao, L., \& Rashid, H. (2010). The mediating role of work-leisure conflict on job stress and retention of IT. Academy of Information and Management Sciences Journal, $13(2), 25-41$. 